\title{
Why Would Anyone Want to Be a Public Interest Lawyer?
}

Philip G. Schrag

Georgetown University Law Center, schrag@law.georgetown.edu

Inaugural Lecture of the Delaney Family Professorship, Georgetown University Law Center, Washington, DC, September 23, 2009

This paper can be downloaded free of charge from:

http://scholarship.law.georgetown.edu/fac_lectures/1 


\title{
GEORGETOWN LAW Faculty Lectures
}

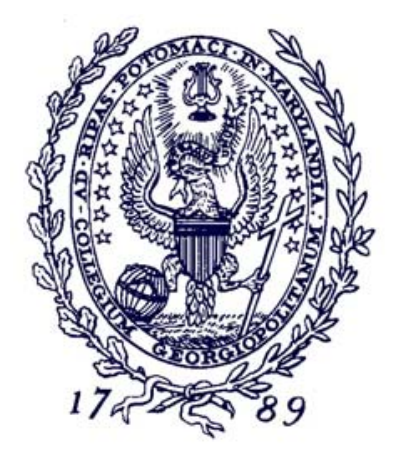

Georgetown Public Law and Legal Theory Research Paper No. 10-52

September 2010

\section{Why Would Anyone Want to Be a Public Interest Lawyer?}

\author{
Inaugural Lecture of the Delaney Family Professorship \\ Georgetown University Law Center, Washington, DC, September 23, 2009
}

Philip G. Schrag

Professor of Law

Georgetown University Law Center

schrag@law.georgetown.edu

This paper can be downloaded without charge from:

Scholarly Commons: http://scholarship.law.georgetown.edu/fac lectures/1/

SSRN: http://ssrn.com/abstract $=1486246$

Posted with permission of the author 


\section{Why Would Anyone Want to Be a Public Interest Lawyer? Philip G. Schrag \\ Delaney Family Professor of Public Interest Law Georgetown University}

Inaugural Lecture of the Delaney Family Professorship

September 23, 2009

I can barely express how grateful the Law Center is to the Delaneys for their generous gift, or what an honor it is to be designated as the first Delaney Family Professor of Public Interest Law at this incredibly vibrant institution. But our celebration today is not merely the recognition of my scholarship or public service. What the Delaneys have done is to honor not only me but also the hundreds of Georgetown students, faculty, staff and alumni who perform public service. Whether they have achieved high office, like Senators Richard Durbin and Patrick Leahy, or provide free legal services for accused defendants in the local courts, or like April Delaney herself, do research, advocacy, or public education in nonprofit organizations, the public interest lawyers who have passed through the halls of Georgetown Law are all encompassed by the Delaneys' vision that public service is the highest calling of those in our profession.

The chair that the Delaneys have endowed is a chair in public interest law. Public interest law is usually defined broadly as legal practice in the service of otherwise unrepresented or underrepresented persons or interests. Public interest law is a wideranging field, encompassing, among other subjects, civil rights law, civil liberties law, environmental protection, international human rights, consumer protection, poverty law, employees' rights, national security, gay rights, education law, election reform, the rights of criminal defendants, corporate reform, children's rights, disability law, and many other subjects. The term public interest law, however, is usually used to refer only to representation of the underdog in each of these areas, such as the representation of minorities against whom discrimination is practiced rather than the defense of those accused of discriminating, and advocacy on behalf of those who want to enforce the Clean Air Act, rather than defending corporations that are accused of polluting the air. That is the sense in which I will talk about public interest law today.

Many of Georgetown's graduates, probably a majority, practice public interest law at some point in their careers, usually by handling pro bono cases at private, for-profit law firms. Georgetown helps equip them to represent unpopular or dispossessed clients in several ways: by offering a first rate general legal education and a vast number of specialized courses and seminars, including at least a hundred courses in various aspects of public interest law; by providing what everyone recognizes to be the best program of clinical legal education in the country; and by immersing its students in a culture of public service that is both a component of the Jesuit tradition and a set of values shared by the full time faculty. The biographies of faculty members in the Law Center's publication "A Community of Scholars" reveals that to a remarkable extent, our faculty is not merely a collection of fine scholars but, if prior employment is any guide, also a group of former full time public interest lawyers who collectively have practical experience in nearly all of the specialties that I have mentioned and many others as well. 
The law firms in which our graduates practice usually give strong support to pro bono representation, sometimes by including pro bono hours as billable hours and often by designating a partner or firm counsel as pro bono coordinator. In addition, the American Bar Association and the state supreme courts have reinforced pro bono representation by making pro bono service an ethical obligation of all lawyers. I must note, however, that this is the most watered down of obligations, because the rule states only that a lawyer should "aspire" to render at least fifty hours of pro bono service a year. While some lawyers provide much more than that, many lawyers do little or no pro bono service.

Although most of our graduates either do full time public service for a year or two before entering the private sector or occasional pro bono representation while in law firms, a small minority of our graduates devote most or all of their careers to public service, and these graduates define themselves as full time public interest lawyers. They spend their entire working lives at non-profit organizations, in government agencies, or both. They do so at significant financial sacrifice, because virtually all of them could have had higher paying private sector careers if they had wanted them. They are aware that the salary gaps between the private sector and the public sector appear large, and that the gap seems to increase all the time. When I graduated from law school, the best-paying law firms offered about twice the starting salary of legal aid lawyers. By 2008, the National Association of Law Placement tells us, median starting salaries in firms with more than 500 lawyers had reached $\$ 145,000$, with some paying $\$ 160,000$, while civil legal aid lawyers began at a median salary of only $\$ 40,000 .{ }^{1}$ In addition, the rate of increase of starting salaries in the private sector continued to outpace the rate in the public sector. Median large firm starting salaries went up by 20\% between 2004 and 2008, while median starting salaries for lawyers at non-governmental organizations such as environmental groups went up by only $12 \%$ over the same period of time. ${ }^{2}$

I teach first year, first semester students every fall, and in their first week of law school, I survey them about what they want to do with the law degrees that they will receive. Usually, the plurality response is that they do not know. They have come to law school in part to find out their options. Some of these undecided students are in the room today. I imagine that given the gap in starting salaries between the private sector jobs and the public sector jobs, some of them must wonder why anyone chooses to make a career in public interest law, and some don't give this option more than a fleeting thought. It is primarily to undecided students that I want to address my remarks today. My point is not to denigrate private sector employment, because without it we would have no economy, and we certainly would lack alumni who can endow professorships or provide other support for the education of future leaders of society. Rather, my purpose is to suggest that there are at least ten sound reasons for giving serious consideration to becoming a public interest lawyer.

The first reason to become a public interest lawyer pertains to the colleagues who are likely to surround you. Almost no one drifts into public interest law. Lawyers choose this work because they believe in causes, and they know that those around them share their basic value systems. As a result, public interest law offices are places where the lawyers, and also the support staff, have a shared mission, which produces a high degree of camaraderie. This may be somewhat less true is very large government agencies than

${ }^{1}$ NALP, New Findings on Salaries for Public Interest Attorneys, http://nalp.org/2008sepnewfindings ${ }^{2}$ Id. 
in public defender offices or in centers that defend unpopular interests, such as those that represent Guantanamo detainees or undocumented immigrants, or those that advocate for the legalization of marijuana. But in general, public interest offices are characterized by cooperation rather than competition, by the friendly social relationships that emerge from a shared enterprise, and by collective celebrations of victories and anguish over defeats.

A by-product of the shared mission is that in many public interest organizations, new lawyers are able to receive outstanding mentoring, though it is usually from peers rather than bosses. This second advantage of public service may seem surprising, because large corporate law firms have long advertised mentoring as a reason to start one's career in the private sector. Unfortunately, as law firms have increasingly become competitive business organizations and their character as guilds has melted away, mentoring in large law firms has become less available than it used to be. But in public interest organizations, solid peer mentoring is a business necessity, because their work would collapse without it. I have been teaching civil procedure for more than twenty years, but my knowledge of how lawsuits are conducted and of the interaction among doctrine, strategy and ethics in civil litigation stems largely from what I learned from William Bennett Turner, who had the office next to mine at the NAACP Legal Defense Fund in the late 1960s. I arrived at the Fund with little more than a three-year old memory of my law school civil procedure course, and I was expected to initiate and conduct lawsuits that would push the boundaries of civil rights and poverty law. I had never seen a complaint, sat in on a deposition, or answered an interrogatory. Turner had graduated from law school shortly before I did, but he spent hours showing me the ropes, and he stuck with me for three years until I had a good feel for what I was doing and was able to assist others. That is the experience often repeated at public interest enterprises, most of which are small enough to be more like families than like corporations. Shortly after he taught me, incidentally, Turner went on to handle a ten-year lawsuit that radically improved the conditions of confinement in the Texas prison system.

The third reason to do this work is that the collegiality in public service extends far beyond one's own institution. Public interest lawyers are part of a large national and international community of like-minded souls who encounter each other through their work, through periodic conferences, and through social contacts. When a civil liberties lawyer from San Francisco meets an environmental justice lawyer from Minneapolis, there is an instant bond, even though the work of the lawyers may have little overlap. They recognize each other as being from the same species, and I have often encountered people who have married within the public interest world. This is of course not surprising, because shared values are at the heart of many successful marriages.

But public interest lawyers are members of more than a community of lawyers. The public interest world includes many allied professions, including social scientists, medical experts, statisticians, social workers, educators, and others. One of the joys of public interest work is the ease of access to like-minded people in these other professions. In the business world, if a lawyer needs to recruit a physician, an engineer, or an historian as a consultant or expert witness, the first issue is likely to be the unpleasant matter of the size of the fee. In public interest work, the issue of compensation is rarely on the table. For example, in Georgetown's asylum law clinic, our students represent people who have sought refuge in America after suffering political or religious persecution in their home countries in Africa, Asia and Latin America. The students often need hours of help and 
detailed affidavits from experts on the countries from which our clients have fled, and from doctors and psychologists who can testify to the physical and mental conditions from which they are suffering as a result of persecution and torture. Most cases also require many dozens of hours of time from people who can translate documents from foreign languages and interpret at interviews with clients. The first question on the students' minds is whether the clinic has a large budget to pay for all this help. And the answer is no. But the students usually discover, to their surprise, that as soon as they tell an expert or translator that they are providing legal services to the client without charge, the expert or translator is also willing to work for free. And indeed, when no one is charging a fee, working with professionals from other fields carries a special pleasure.

The fourth reason to become a public interest lawyer is the large degree of responsibility that is given even to beginners. On my first day at work, in my first job as a lawyer, I actually had the experience that people had joked about at law school. I arrived at the NAACP Legal Defense Fund office, fresh from taking the bar exam, and introduced myself as the new lawyer whom they had signed up the previous spring. My boss, Leroy Clark, who later became the General Counsel of the Equal Employment Opportunity Commission, and then an eminent law professor, greeted me. "Oh, we're so glad you're here," he said. "We've promised to write an amicus brief in a Supreme Court case involving the First Amendment. Everyone else is busy on other projects. So here is your office and an air travel credit card. Go anywhere you need to go, and talk to anyone you need to talk to, but please have the brief on my desk in 25 days."

Not everyone gets assigned a Supreme Court brief on the first day of the first job, but getting heart-thumping responsibility right away, which almost never happens in large corporate law firms, is common in public service. For example, if you were to go to work for the Attorney General of the District of Columbia, you might not have a carpet on the floor of your office, but you will probably be responsible for litigation and handling trials within a matter of weeks if not days. Why? Because public and nonprofit agencies are so strapped for cash and other resources that they simply don't have enough people to cover the work they need to do. They can't waste the time of even their most junior lawyers. And unlike large private law firms, which bill for each hour that each associate spends on a matter, they have no incentive at all to have more people working on a case than is absolutely necessary, or to build redundant supervisory hierarchies.

A fifth reason to become a public interest lawyer relates to the flexibility or versatility that this type of practice offers. Lawyers in private practice tend to become specialized. If they are very good at corporate taxation or municipal bonds or biological patents, they are likely to spend decades if not their entire careers in those particular specialties. They are sometimes able to switch fields, but it isn't economical for a bored copyright lawyer with fifteen years experience, or for her employer, to be retooled as a water pollution lawyer, and it isn't easy to attract clients who will pay at high rates for someone just learning a new field. Public interest lawyers have a greater degree of mobility, because many people see the relevant specialty not as a particular subject matter but as public interest law itself, or at least a set of broad skills such as public advocacy in Congress, public interest litigation, or nonprofit administration. Over a period of about 40 years, I have been a civil rights lawyer, a consumer protection lawyer, a public housing eviction lawyer, a nuclear arms control negotiator, a social security disability lawyer, a DC statehood advocate, a legal ethics lawyer, and an immigration lawyer. My professional 
dilettantism may be extreme, but many of my former students have worked in three or four radically different settings within a decade or so, learning from each of them. For example, one of them, who is here today, went to work as an immigration lawyer for a relief organization in New York, then became a staff member at an international human rights organization, then moved to the office of a U.S. Senator, then joined the staff of the Senate Finance Committee and is now running a social justice center at a law school in New Hampshire. Another started her professional life at a traditional human rights organization, then started her own organization, Witness, which has trained human rights workers around the world to make video documentaries of abuses in their countries, and she is now the director of a new organization, 1Sky, that is seeking international solutions to global warming.

Now here's a surprising sixth reason to become a public interest lawyer: you might do it for the money. While starting and ending salaries are higher in the largest law firms than in public service, not everyone starts in large law firms, especially these days, and even in better times, because of their pyramid structure, very few people end in them. On the other hand, median public service incomes may be a lot closer to median private firm incomes than many people realize. The disconnect between perception and reality comes about for two reasons. First, many students focus on the top starting salaries that the biggest firms pay, rather than median private sector starting salaries. Second, most graduating students compare only starting salaries, which I described earlier. Very few graduates who contemplate public service inquire how much the lawyers earn in their fifth or tenth year at the organizations in which the graduates are interested. And very few organizations offer this information to potential recruits. In fact, about ten years ago when I tried to survey major public interest organizations about what incoming lawyers might expect to earn in five years, even most of the senior lawyers had no idea; they didn't know the salaries of anyone in the organization other than themselves, and the executive directors were loathe to provide numbers because future raises depended on future fund-raising, making historical numbers unreliable. But it seems that starting salaries in the nonprofit world are artificially low because those low salaries are used to test commitment and enthusiasm, and that once a lawyer has been at such an organization for a year or two, annual percentage increases are likely to be higher than in many law firms, making it possible to earn a quite decent living after a while. In government service, for example, raises are fairly reliable and also substantial. A lawyer who starts life in the federal government, in Washington, D.C., at the GS-11 level begins with a salary of $\$ 61,000$. That lawyer will be earning $\$ 70,000$ at the end of five years, even if the GS scale is not adjusted for inflation, which periodically occurs, and even if she has not had a single promotion to a higher GS level. With promotions, that salary at the end of five years can be $\$ 121,000$. The current ceiling on the salary of a federal government lawyer who is not in a senior executive position is $\$ 153,000$, far below what large law firm partners take home, but enough for most such lawyers to live on comfortably and to raise a family, particularly if the family has two earners. And of course these days, when nearly 10,000 private sector lawyers have been laid off since the beginning of 2008, a government job may be a lot more secure than a job in a private firm.

In addition, public interest lawyers are often eligible for substantial student loan forgiveness programs from law schools, states, and the federal government, making their real income significantly higher than their salaries. And loan forgiveness under most of these programs is tax exempt. 
The seventh advantage of a career in public service is that you can have a life outside of your office. A substantial literature documents the unpleasant fact that while large law firms pay double salaries, they require associates, and also many partners, to work nearly double hours. Work weeks of 66 to 72 hours are common, making it very difficult for associates to enjoy the company of spouses or children, or to have hobbies, recreation, or leisure. ${ }^{3}$ Smaller law firms require fewer hours at the office, but many lawyers in such firms find themselves spending nearly all their time working because they have to spend so much time cultivating potential clients at community meetings and social events. ${ }^{4}$ Many public interest lawyers work very long hours when projects are white hot, but at other times they have schedules that are more similar to those of other white collar workers, with correspondingly greater ability to have close relationships with family members and lives that are balanced between work, play and rest.

I don't want to overstate the point, but there is a certain deep truth to the game of Careers that most of us played as children, or for us older folks, played with our children. In that game, hearts represent happiness, stars represent fame, and dollars represent money. To win the game, you have to get to 60, but early in your simulated life, you must commit on paper to the precise balance of hearts, stars and dollars that you will seek in order to get to that number. The game teaches that there are often tradeoffs in life among happiness, fame, and money, and that early decisions may determine one's future balance among these categories. Surveys of lawyers show that the tradeoffs are real and that while those who represent private corporations tend to collect the most dollars, public interest lawyers are a happier group of people. A higher proportion of them achieve some sort of fame as well, in their own communities if not nationally or internationally.

I have saved for last the three best reasons for becoming a public interest lawyer. Reason number eight is that except in certain large government bureaucracies, the work is rarely routine. Public interest lawyers get to work on cutting edge issues all the time. That's the very nature of public interest work: it is law-reforming, a challenge to the status quo. Take any headline. Who has been the leader in seeking habeas corpus relief for Guantanamo detainees? The Center for Constitutional Rights, a public interest organization. Who has represented the government's interest in preventing their release? The Department of Justice, a public interest organization. Who is inventing a new system of health care for the United States? Lawyers on the staffs of House and Senate committees, which are public interest organizations. Who are the people trying to fix the financial and economic systems that are in crisis? Lawyers and economists in the Treasury Department, a public interest organization. Who are the people at the forefront of the battle to end capital punishment? Public interest lawyers at organizations across the country, including several who are Georgetown alumni and teachers. Who was the plaintiff in the Massachusetts State Supreme Court case that broke open gay marriage in America? One of my former students. Who defended traditional marriage in that case? Lawyers working in the office of the Attorney General of Massachusetts, a public interest organization. Who has put together a coalition of 425 organizations to lobby Congress

\footnotetext{
${ }^{3}$ See, particularly, Patrick J. Schiltz, On Being a Happy, Healthy, and Ethical Member of an Unhappy, Unhealthy, and Unethical Profession, 52 VAND. L. REV. 871 (1999) as well as other sources cited or excerpted in Chapter 13 of Lisa G. Lerman and Philip G. Schrag, ETHICAL Problems IN THE PRACTICE OF LAW (2d ed. 2008).

${ }^{4}$ See Carol Seron, The Business of Practicing LAW (1996).
} 
for legislation to reverse global warming? Another of my former students. Who are the people in the forefront of litigation that is defining how free and open the internet will remain? Several more of my former students. Open any newspaper. Of course there is news, every day, about the work of lawyers for corporations and other business organizations. But look at the main headlines, and you will find much more news involving the work of public interest lawyers, because they work every day on the issues that make national and international news. Even public interest lawyers who represent individual low-income clients in welfare or housing cases are challenging the status quo and inventing new procedures and doctrines for their clients. While their work less often makes headlines, they frequently reform the institutions that hold power over their clients.

Ninth, consider this: practicing public interest law is fun. It's fun because when they are successful, public interest lawyers usually turn the tables on more powerful institutions, and it's fun because upsetting the status quo forces you to be creative and innovative.

Think about it: which would be more fun and more creative, being Goliath and smashing little David with a club, or being David felling Goliath with a stone? How much joy does a tobacco company's lawyer get out of defeating a widow who sued the corporation after her husband died of lung cancer? On the other hand, what was the pleasure level of the state attorneys general who won the first cases ever against the tobacco industry? With apologies to the OPICS staff, who have already heard this story, let me offer you a personal account from my fourth year as a lawyer, when I worked for the New York City Department of Consumer Affairs. A company that I will call Foolproof Alarms was having salesmen go door to door to sell burglar alarm systems, often to robbery victims, using fraudulent statements to persuade them to sign installment contracts to buy the alarms. It had sold 16,000 alarms in three years. The customers obligated themselves to pay $\$ 500$ in monthly installments for alarms that were worth only $\$ 75$. The customers often discovered they had been cheated and stopped paying, and the company sued them so frequently that it was the fifth most frequent litigant in New York's courts.

On this case I worked with Bruce Ratner, a lawyer fresh out of Columbia Law School. Bruce and I considered suing Foolproof for fraud, but we knew that such a suit would take years, and judges in New York were reluctant to grant preliminary injunctions, even at the behest of the government. As a home improvement contractor, Foolproof was licensed by the City, and we could have commenced a license revocation proceeding, but that too would have required months of work and years of appeal.

As a licensee, Foolproof had a legal obligation to let us inspect its books and records. Ratner went to Foolproof's headquarters and for three days and three nights, until midnight, he looked over the records. Eventually, the company got so used to his presence that they let him see and copy whatever he wanted. In this way, he got access to the crown jewels: that is, he was able to make copies of the index cards on which Foolproof kept the names and addresses of all of its customers. He thought that in a fraud suit, we would be able to select articulate witnesses from this large set of names.

But we actually got something better out of the list. A New York law required all door to door salesmen to give customers a pre-addressed card that they could mail to the seller, within three days, to cancel a door to door sale. If they provided the card, the right to cancel lasted only three days, but if they failed to provide the card at the time of the sale, 
the right to cancel lasted until three days after the card was provided. And the seller would have to return all prior payments to a customer who cancelled.

We thought that Foolproof might not have given out the cards, in which case thousands of defrauded consumers could still cancel their contracts. On that assumption, we prepared thousands of notices of the right to cancel, with pre-stamped postcards that would cancel the contracts. We also prepared covering letters about the true value of the alarms, and we addressed them to the thousands of people whose names and addresses were on the index cards. If most of them responded by cancelling, Foolproof would have no accounts receivable and it would have to make enormous refunds. Because it was cash-short, and its credit would be ruined, it would have to go out of business, and it wouldn't be able to sue anyone any more.

It took a couple of weeks to prepare our huge mailing. At last we were ready to go. But we still didn't know whether Foolproof had actually distributed cancellation cards or had failed to distribute them. To find this out, we waited until we were ready with the mailing, so that asking about it wouldn't tip off Foolproof and give it a chance to mail its own cards with its own message. We asked Foolproof's general counsel to come into my office, and for about ten minutes, we engaged him in conversation about minor aspects of the business. Then Ratner asked offhandedly, "By the way, has Foolproof been giving out the three-day cancellation cards required by the state law?" He replied, "Oh no, that's one of the laws we haven't gotten around to complying with yet." We talked for another ten minutes. He left my office, and closed the door behind him. I have to admit that what happened next was very undignified. When the door closed, Bruce and I quite literally danced around the office. When we finished dancing, we visited the mailbox.

Vast numbers of customers canceled their contracts. Foolproof's economic condition spiraled downward in the following weeks, as the company staggered under the effects having to make refunds. ${ }^{5}$ But this was the first big blow to the company, and our creative approach to law enforcement eventually resulted in the bankruptcy of Foolproof, the cancellation of all that consumer debt, and the indictment of Foolproof's president on thirty eight counts of grand larceny.

\section{That was fun.}

Finally, although my talk up to now has concerned the wonderful things that practicing public interest law can do for the lawyers, let me turn, as reason number ten, to the conventional reason to choose public interest law: the service that public interest lawyers can provide for people in need. Albert Einstein said, "Striving for social justice is the most valuable thing to do in life." Public interest lawyers spend their lives in that pursuit. Most public interest lawyers represent people or institutions that are unable to obtain legal representation from the private sector for one of three reasons: either they are so unpopular that no one is willing to represent them for a fee; or what they need from a lawyer (such as the establishment of a principle, or recovering a small amount of money, or avoiding a small judgment) would not generate or warrant a fee, or the client simply is too poor to pay a fee.

\footnotetext{
${ }^{5}$ For the full saga, see Philip G. Schrag, Counsel fOR THE DECEIVED (Pantheon Books 1972)
} 
Therefore, public interest lawyers are always helping people in need, sometimes in great need, who desperately need their alliance with a professional, an alliance that is often particularly strong because it is not mediated by money. Public interest lawyers make huge differences in the lives of many people, whether through keeping them housed, limiting the amount of time they spend in jail or improving the conditions of their confinement, helping them to become employed or re-employed, enabling them to go to school, preventing them from being cheated, enabling them to enjoy physical security or an unpolluted environment, and in so many other ways. Public interest lawyers also help clients to understand how to exercise power, to advocate effectively for themselves even when the lawyers are no longer representing them.

Along with my clinic Fellows and students, I have spent much of the last 14 years representing individual would-be immigrants whom the Department of Homeland Security is trying to deport. These individuals are applicants for political asylum who assert that they have a well-founded fear of persecution in their home countries. In many cases, they have already been imprisoned by the governments of those countries, subjected to electrical shocks, raped, their skin burned, sometimes their heads beaten so badly that they have permanent brain damage. The U.S. government challenges their claims, and we represent these asylum-seekers, without charge, in federal immigration court. So several times each spring, I observe my students present evidence in hearings that typically last for four hours. At the end of these hearings, the judge announces the decision from the bench: either an order that the applicant should be forcibly removed to the country he has fled, or an order granting asylum and welcoming the applicant to the United States, in which he now is likely to become an American citizen. These are often life or death decisions, and we usually win. I can hardly convey to you how much success means to our clients, or how much all of us - students and teachers alike - are also deeply affected by our contact with these clients and by success in these cases. Those moments when the judge grants asylum and leaves the courtroom, and in which everyone else, client, students, supervisors, and even sometimes the court's interpreter, begins to cry - those are the moments when I am proudest to be a public interest lawyer, and when I most feel that I have done something tangible and concrete to improve the life of another person.

So I say to my students who are here today: whether you do public service as a part time pro bono activity or as a life's mission, I hope that many of you will experience the incredible satisfaction of providing service to people who need it and can not pay for it. You have the inclination to serve because of the generosity that is already in your hearts and your awareness of the privileges that have been bestowed upon you by your families and your nation. And in a very short time, you will have the ability to serve the public because you will graduate with skills and insights that you are now acquiring through your studies, thanks in significant measure to the Delaney family and to the other wonderful friends and alumni of Georgetown Law. 